\author{
MARTYNA DESZCZYŃSKA \\ Biblioteka Narodowa - Instytut Książki \\ i Czytelnictwa
}

\title{
UWAGI O TEORII SEKULARYZACJI I SEKULARYZMIE W NAUKACH HUMANISTYCZNYCH
}

W Podróży dwudziestej pierwszej z Dzienników gwiazdowych Stanisław Lem opisał konflikt między wiedzą a metafizyką, postęp równoznaczny z ograniczaniem metafizyki i wykluczaniem transcendencji, wieszczył powrót do neognozy, panteizmu i zanegowania duchowego wymiaru człowieczeństwa. Ustami jednego z bohaterów nazwał próby ograniczenia transcendencji „pokusami diabelskimi”, choć nie był to jego własny pogląd autorski:

Jeżeli to miały być pokusy diabelskie, to wszystko, czego się tkniesz, jest diabelską pokusą, i nie można by nawet powiedzieć, że Szatan pochłonął cywilizację, ale w niej Kościoła nie pochłonął, ponieważ Kościół, choć z oporami, daje stopniowo zgodę na zdobywanie wiedzy, i nie ma na tej drodze żadnego miejsca, na którym mógłby rzec „dotąd, a dalej już nie!”, ponieważ nikt, w Kościele czy poza Kościołem, nie potrafi wiedzieć, jakie będą jutrzejsze skutki dzisiaj poznanego. [--] Wolność oznacza dla nas coś zupełnie innego niż dla ciebie. Oznacza ona upadek wszelkich ograniczeń działania, czyli zanik tych wszystkich oporów, jakie życie napotyka na swym zaraniu rozumowym. Te opory kształtują rozum, bo wydobywają go na wierzch z wegetacyjnych otchłani. Ponieważ te opory dają się dotkliwie we znaki, historycznemu rozumowi roi się jako ziszczenie pełnia swobód, i dlatego właśnie w tym kierunku zmierza cywilizacyjnymi krokami. Jest krok ciosania kamiennych urn i jest krok wskrzeszania zmarłych, i jest krok gaszenia słońc i nie ma między nimi nieprzebytych przeszkód. Wolność, o jakiej mówię, to nie ten skromny stan pożądany przez jednych ludzi, kiedy inni ich dręczą. Wtedy bowiem człowiek jest dla człowieka kratą, ścianą, sidłami i przepaścią. Wolność, którą mam na myśli, leży dalej, rozpościera się poza tą strefą socjalnych zdławień wzajemnych, ponieważ strefę tę można przejść cało, a wtedy, w poszukiwaniu nowych oporów, bo ich już ludzie ludziom nie stawiają, odnajduje się 
je w świecie i w sobie i wybiera się za przeciwnika siebie i świat, żeby z obojgiem walczyć i oboje sobie podporządkować. A kiedy i to się udaje, otwiera się otchłań wolności, ponieważ im więcej można czynić, tym mniej się wie, co czynić należy ${ }^{1}$.

Ów cytat pochodzi z dialogu bohatera Dzienników, Ijona Tichego, z inną postacią - o. Dargiem. Tichy przybywa na planetę Dychtonię, do świata zmienionego genetycznie w imię możliwości postępu i nieograniczonej woli jego mieszkańców. Zwyciężyły tam „rewolucje biotyczne”. Dawny wygląd Dychtonian, podobny do ziemskiego, jest na tej planecie niecenzuralny i „niepostępowy”, bo zwykły. Godności i wiary w wymiar transcendentny strzegą antropomorficzne roboty, zwane ojcami Destrukcjanami, zorganizowane w społeczność na wzór klasztoru, z „przeorem” Dargiem na czele. Ojcowie-roboty maskują się, używając przebrań i protez. Modlą się w katakumbach i ruinach, gdzie strzegą ksiąg dawnej kultury i tradycji. W historii Dychtonii wyznawano „duizm” - wyzbytą z dogmatów wiarę w Boga. Zniesiono tam dogmat o nieśmiertelności duszy, zakwestionowany przez technologię zamrażania, „odwracania” (rozdzielania zygoty na plemnik i komórkę jajową) oraz „uduchowiania” (wszczepiania wrażeń duchowych sztucznym inteligencjom). Wiedzę o upadłej cywilizacji Tichy zdobył, kryjąc się przed zbrojnymi komandami „postępu biotycznego”, analizując zjawiska przewidywane. Darg podkreślał, że gość nie będzie mógł zrozumieć jego wyjaśnień, choć obszernych, gdyż są one w innym od ziemskiego porządku ontologicznym i epistemologicznym. Odesłał Tichego do lektur z klasztornej biblioteki.

Ten mini-traktat filozoficzny jest prowokacją intelektualną filozofa-pisarza wobec etosu religijnego. Futurologiczny wymiar tekstu Lema zawiera pytania inteligenta, filozofa, futurologa i sceptyka, inspiruje czytelnika i w XXI w. Żyjący w stuleciu wcześniejszym Lem, z wykształcenia lekarz, z zamiłowania naukoznawca, był przykładem ewolucji intelektualisty, podążającego od idei humanistycznych i powołania lekarskiego do pełnej dylematów postawy krytyka świata, wewnątrz którego tkwi ludzka psyche i physis. Zafascynowany nauką i granicami poznania, nie wierzył w Boga i w życie na innych planetach. Pytał o granicę wolności i wolnej woli, o miejsce idei Boga w planie poznawczym, odczytanie własnej kultury, o ewolucję cywilizacji, etyki, sztuki, o esencjalny i fenomenologiczny wymiar człowieczeństwa.

Inspirującą rolę Lemowych pytań o universum idei i wyobrażeń, którymi posługują się dziś nauki humanistyczne, można rozwinąć i odnieść

${ }^{1}$ S. Lem, Podróż dwudziesta pierwsza, w: idem, Dzienniki gwiazdowe, Kraków 1957 (cyt. wg: wyd. rozszerzone, Kraków 1982, s. 255 n.). 
do wpływów postmodernistycznych w historiografii albo pojęć sekularyzacji i sekularyzmu i ich skutków w nauce. W niniejszym szkicu zajmę się szczególnie tymi ostatnimi, pod kątem ich znaczenia dla historyka religii.

Bogata tradycja dyskusji o religii i jej ewolucji w społeczeństwie, poczynając od myślicieli wczesnooświeceniowych przez socjologów przełomu XIX i XX w. (Émile'a Durkheima czy Maxa Webera) aż po czasy współczesne, upoważnia nas do wglądu we współczesny stan owej dyskusji. Wiódł ją na polu empirii m.in. José Casanova, uważający, że sekularyzacja jest schyłkiem religijności, oraz Grace Davie, autorka koncepcji tzw. religijności delegowanej. W nurcie postmodernizmu autorzy tacy jak neopragmatyk Richard Rorty czy filozof i zarazem poseł Parlamentu Europejskiego Gianni Vattimo odnieśli się do zjawisk sekularyzacji w aspekcie dechrystianizacyjnym. Ostatnie stulecie było też świadkiem narodzenia się sekularyzmu, czyli wizji człowieka współczesnego egzystującego w przestrzeni programowo bez Boga. Sekularyzm dąży do stanu, by człowiek w swej aktywności pomijał wszelką transcendencję. Promuje mentalność naukowo-techniczną, będącą spadkiem po scjentyzmie i progresywizmie XIX w. Teologia chrześcijaństwa zachodniego wyjaśnia sekularyzm za pomocą uznania autonomii i wolności myślenia (w ujęciu doktryny o wolnej woli) oraz sensowności doczesnego świata ${ }^{2}$.

Historyk religijności zawsze będzie stawiać pytanie o korzenie erozji chrześcijaństwa w świecie zachodnim. Zazwyczaj wymienia się idee, które uruchomiły ten proces: deizm, sekularyzację, scjentyzm, laicyzację i właśnie sekularyzm. Uważa się, że główną przyczynę erozji wierzeń (a więc dechrystianizacji Europy) stanowił, obok uwarunkowań kulturowych, zanik podstaw intelektualnych $\mathrm{w}$ odniesieniu do religii ${ }^{3}$. Wskazuje się na uwiąd wiedzy z zakresu logiki, filozofii, laciny, liturgii, teologii, rozumienia tekstu pisanego oraz znajomości symboliki alegorii i przenośni, a więc kompetencji literackiej. Byłoby oczywiście uproszczeniem szukanie przyczyn sekularyzacji i dechrystianizacji w umasowieniu piśmienności, spłycającej tę sferę wykształcenia, która uwrażliwiała religijnie.

Słów kilka poświęcę deizmowi. Wywodzący się z siedemnastowiecznej myśli angielskiej, ugruntował i rozwinął się w XVIII w., różnicując się na kilka postaw, takich jak materializm, agnostycyzm i ateizm. Oddziałując

2 J. Mariański, Sekularyzacja i desekularyzacja we nowoczesnym świecie, Lublin 2006, passim; E. Voegelin, Od Oświecenia do rewolucji, wstęp P. Śpiewak, Warszawa 2011 (oryg. ang. 1975), s. 135-138, 221-229.

${ }^{3}$ R. Hajduk, Przyczyny erozji wiary chrześcijańskiej, w: Kontrchrześcijaństwo jako kontekst działalności misyjnej w XXI wieku, red. P.A. Sokołowski, Pieniężno 2009, s. 43. 
w Europie, wraz z rozwojem nauk przyrodniczych i techniki zmienił świadomość religijną i jest obserwowany w większości postaw tzw. religii bez dogmatu. Obraz świata ze „stworzonego" przeobraził się w „stwarzalny”, został „odczarowany”, przestał być środowiskiem homo religiosus, stał się areną homo faber. Podkopało to religijny, a właściwy także dla innych religii, pogląd o szczególnym stosunku Stwórcy do świata - owocując konceptem „nieingerencji”: Stwórca nadał prawa naturalne, enigmatycznie rozumiane, by następnie oddalić się. Zanikła idea Opatrzności, "usuwano dogmaty" centrycznych „idei narracyjnych”. Nie miejsce tu, by spierać się, która z tych idei była sprawcza: humanizm, prawo natury czy fizjokratyzm. Bez wątpienia zaś zaliczały się do nich (lub z nich wynikały, jako projekty ,przekształceniowe”): scjentyzm, pozytywizm, socjalizm, komunizm, ewolucjonizm, faszyzm, nazizm.

Kolejne pojęcie to sekularyzacja, rozumiana jako utrata wpływu instytucji religijnych na społeczeństwo (w potocznym rozumieniu utożsamiana z laicyzacją). Wymaga głębszego zainteresowania teoretyczno-metodologicznego. Definicja, na którą można się zgodzić, oznacza proces ,uwalniania się różnych elementów obszarów ludzkiego życia (np. poglądy, obyczaje, formy życia społecznego, a nawet rzeczy i osoby) albo ich całokształtu spod dyktatu religii", w odróżnieniu od sekularyzmu, który jest rezultatem tego procesu i stanowi jakby program światopoglądowy sekularyzacji ${ }^{5}$. Sekularyzacja tak rozumiana zaczęła się w Europie nowożytnej, a „przyspieszyła” w oświeceniu i erze współczesnej. Przejawia się w postawach utylitarnych, konsumpcyjnych, przy programowym agnostycyzmie i antyklerykalizmie jako wyznacznikach nowoczesności, ale też elementach zastępujących tzw. próżnię po metafizyce.

Tymczasem zjawisko sekularyzacji (szczególnie strefy euroatlantyckiej) okazało się ewenementem. Odwrót od religijności wystąpił wyłącznie tu, na obszarze kultur czerpiących z chrześcijaństwa i korzeni judeo-klasycznych, obejmując poza Starym Kontynentem, oboma Amerykami, dodatkowo Australię i Nową Zelandię (ale już nie południową Afrykę; sytuacja w Rosji i Izraelu jest złożona). Niezaprzeczalności i historycznych korzeni sekularyzacji i sekularyzmu dowodzą zmiany w edukacji i życiu społecznym od XVIII w. po współczesność, takie jak np. zanik praktyk konfesyjnych

${ }^{4}$ J. Braun, Sekularyzacja teologii a polska filozofia XIX wieku. Odczyt wygłoszony na IV Międzynarodowym Kongresie „Centro di Studi Internazionale” 24-29 IX 1977, b.m., 1977, s. 2; P. Mazanka CSsR, Źródła sekularyzacji i sekularyzmu w kulturze europejskiej, Warszawa 2003, s. 177-304.

${ }^{5}$ Sekularyzacja, w: Leksykon religii, wyd. H. Waldenfels, Warszawa 1997 (oryg. niem. 1987), s. 432. 
w miejscach publicznych, kasaty zakonów i bractw, propaganda głosząca treści świeckie i antyreligijne. Rola państw w tym procesie była spektakularna, głównie poprzez desakralizację symboliki narodowo-państwowej, prywatyzację religii, aż w końcu programową obojętność światopoglądową. Ów eurosekularyzm i modernizacja uważane są przez obserwatorów ze świata islamu czy buddyzmu za zjawisko o znaczeniu lokalnym, oparte na chrześcijańskim rozumieniu czasu ${ }^{6}$. Tym bardziej że sama europejska refleksja nowoczesna nad historią przyniosła np. pogląd Johanna W. Goethego definiujący ją jako walkę między wiarą a niewiarą ${ }^{7}$. W tym rozumieniu da się zauważyć sekularyzm i w uprawianiu nauk. Polegał on na separacji wydziałów teologicznych od reszty uczelni, tworzeniu zakładów programowo świeckich, wreszcie na marginalizacji i wykluczeniu osób otwarcie wyznających światopogląd religijny z gremiów oraz środowisk miarodajnych i opiniotwórczych. Wtórna adaptacja przez sekularyzm języka, form językowych i pojęć nawiązujących do sacrum wpływa na kulturę, komunikację społeczną, zwłaszcza internet i blogosferę. Pojawianie się „cmentarzy internetowych” dla ludzi i zwierząt - czy innych form parareligijnego upamiętnienia w sieci - jest skutkiem wpierw sekularyzacji, potem zaś sekularyzmu ${ }^{8}$.

Przejdźmy zatem od praktyki i egzemplifikacji do teorii sekularyzacji jako takiej. To rozróżnienie: „sekularyzacji” jako kategorii badawczej od „sekularyzacji” jako zjawiska dowiedzionego empirycznie ma bowiem kluczowe znaczenie w historiografii kultury, obyczajów czy religii ostatnich 250 lat. Teoria ta znajdowała się od czasów oświecenia pod wielką presją ideologiczną - wszak widziano w niej czynnik postępu. W pierwszym znaczeniu, jako paradygmat, termin ten stał się narzędziem opisu naukowego. Choć podkreślano jego nieprecyzyjność, to „obiektywnie” stosowano go w analizie wszelkich wariantów kultury wywodzących się z Europy - jest on czymś w rodzaju idée fixe socjologii religii ${ }^{9}$. Nie miał zapewne tego na celu Gabriel Le Bras, który przed II wojną światową badał sekularyzację i dechrystianizację we Francji, szczególnie na wsi. Nie tworzył bowiem uogólnień. Nieco odeń młodszy Peter L. Berger, przedstawiciel socjologii fenomenologicznej, autor książki Święty baldachim: elementy

${ }^{6}$ R. Chymkowski, Arabskie przebudzenie. Modernizacja i postkolonializm, „Kultura Współczesna" 2014, 1, s. 48.

${ }^{7}$ M.Żmudziński, Pojęcie „śmierci Boga” i jego oświeceniowa geneza, w: Laicyzacja i sekularyzacja społeczeństwa nowożytnego (XVI-XVIII w.), red.J. Wiśniewski, Olsztyn 2008, s. 221.

${ }^{8}$ Zob. Religijność $w$ dobie popkultury, red. T. Chachulski, J. Snopek, M. Ślusarska, Warszawa 2014.

${ }^{9}$ K. Zielińska, Sekularyzacja wedtug Karela Dobbelaere'a, w: K. Dobbelaere, Sekularyzacja. Trzy poziomy analizy, Kraków 2008 (oryg. ang. 2002), s. 11. 
socjologicznej teorii religii z 1967 r. (1. wyd. polskie - Kraków 1997), teorią sekularyzacji jako tezą bez dowodu posługiwał się na co dzień. Wnikliwy zaś J. Casanova powiązał oba jej rozumienia, twierdząc, że teoria ta zawiera tezę o konceptualizacji procesów modernizacji ${ }^{10}$. Pozorne więc unaukowienie tego kontrowersyjnego narzędzia i stworzenie zeń na powrót rzekomo koniecznego elementu opisu dziejów dało mu sankcję na tyle mocną, że zakorzeniło się w naukach humanistycznych.

W ostatnich dziesięcioleciach zanegowali ją wszak Rodney Stark i William S. Bainbridge, określając mitem, a przewidując raczej rozwój niż uwiąd religii w przyszłości ${ }^{11}$. Jeffrey Hadden zaś nadkruszył potęgę teorii sekularyzacyjnej, odbierając jej prymat jako metody wyjaśniającej ${ }^{12}$. Hilary M.Carey podważyła korelację między sekularyzacją a modernizacją wśród protestantów kanadyjskich i nowozelandzkich ${ }^{13}$. Do tego kruszenia pozornego obiektywizmu teorii sekularyzacji nawiązał ostatnio Brad S. Gregory w badaniach nad reformacją ${ }^{14}$. Lokalność teorii sekularyzacji ogranicza jej przydatność do wyjaśniania wtórnych poszukiwań religijnych, rozwoju sekt i New Age.

Teoria sekularyzacji pozostaje więc nadal teorią, i to kwestionowaną przez socjologię. Choć utraciła swą siłę, to ciągle przejawia się w niektórych nurtach historiografii, zwłaszcza w podręcznikach jako element wyjaśniania. Idea sekularyzacji była więc na tyle skuteczna w nauce, że w sposób niezamierzony wpłynęła na jej kształt, poprzez stworzenie właśnie „teorii sekularyzacji". Samo zaś zjawisko zeświecczenia jako element ideologii (teza bez dowodu) nie musiało być prawdziwe, by oddziaływać, choć niekiedy przeczyła mu rzeczywistość ${ }^{15}$.

Kwestionowanie tzw. wielkich narracji, w tym religijnych, dających całościową wizję człowieka, spowodowało, że postmodernizm ma problem z sekularyzmem. Sam sekularyzm jako tzw. idea przekształceniowa zderzył się z neognozą i New Age, gdyż nie daje się pogodzić z inwencją

${ }^{10} \mathrm{~J}$. Casanova, Religie publiczne w nowoczesnym świecie, Kraków 2005 (oryg. ang. 1994), s. 43.

${ }^{11}$ R. Stark, W.S. Bainbridge, Future of Religion. Secularization, Revival and Cult Formation, Berkeley 1986. Tego zdania był Thomas Luckman (Theories of Religion and Social Change, „The Annual Review of the Social Sciences of Religion” 1, 1977).

${ }^{12}$ J. Hadden, Desacralizing Secularization Theory, w: Secularization and Fundamentalism. Reconsidered Religion and The Political Order, red. idem, A. Shupe, vol. 2, New York 1989.

${ }^{13}$ H.M. Carey, God's Empire. Religion and Colonialism in the British World, c. 1801-1908, Cambridge 2011.

${ }^{14}$ B.S. Gregory, The Unintended Reformation. How a Religious Revolution Secularized Society, London 2012, s. 25-73 (rozdz. „Excluding God”).

${ }^{15}$ Por. C. Veltman, Holandia: Sekularyzacja w odwrocie?, „Więź” 49, 2006, 12 (578): Sekularyzacja droga Europy?, s. 36. 
religijną i poszukiwaniami duchowymi. Na miejsce religijności tradycyjnej weszły zjawiska znajdujące się na obrzeżach ortodoksji lub całkiem z nią sprzeczne, takie jak gnoza, neognoza, martynizm, ezoteryka, spirytyzm, teozofia, okultyzm ${ }^{16}$. Pojawiły się strategie językowe zaburzające przekaz ortodoksyjny. Np. w neognozie jest to przedefiniowanie treści, dodawanie treści nowych do formuł dogmatycznych, zmiana zakresu odniesień, zmiana wartości poznawczej, czyli przewartościowanie poznawcze, a także przemilczenie, czyli przedefiniowanie kontekstu ${ }^{17}$. Współcześnie widać też powrót do religii wymarłych pod wpływem szerzenia się wiedzy o nich wśród edukowanych pobieżnie odbiorców, którzy w duchową pustkę wbudowują wygasłe kulty i stają się pierwszymi ich wyznawcami. Przykładem jest odnowienie kultu Isztar wśród archeologów brytyjskich, rozwijająca się moda na panteon słowiański i bałtycki w Rosji, Polsce i Litwie czy rozwój pedagogiki waldorfiańskiej, wyrosłej z antropozofii na tle popularności tzw. New Age ${ }^{18}$.

Świeckość absolutna stała się nieosiągalna, jak wiele z idei XVIII w. R. Rorty, określając się „laickim antyklerykałem”, początkowo uznał przekonania religijne za niebezpieczne, a człowieka współczesnego za żyjącego spokojnie i bez lęku w świecie półprawd. Najważniejszym celem współczesnej kultury obwołał dążenie do pełnego „programu sekularyzacyjnego" ${ }^{19}$. Pytał, sugerując odpowiedź, czy konieczne jest uwzględnianie w przestrzeni społecznej głosów o charakterze religijnym. Ostatecznie Rorty, tworząc koncepcję „liberalnej ironistki”, zmagającej się z przygodnością świata bez matafizyki, postulował używanie takiego słownika pojęć, jakiego chce każde indywiduum.

Postmodernistyczny sekularyzm nauki zamiast obiektywizmu prawdy proponuje różne odcienie i warianty opinii, mówiąc, że prawda nie istnieje. Woli mikronarracyjność - co w badaniach historycznych skutkuje rozwojem studiów regionalnych, badań pograniczy i mniejszości kulturowych, etnicznych i seksualnych oraz kultem wolności rozumianej jako negacja wszelkich zakazów. W historiografii i humanistyce zapanowała wskutek tego Derridowska „różnia”, czyli różnicowanie (franc. differénce zamienione

${ }^{16}$ W. Myszor, Elementy gnostyckie w nowej duchowości, w: Gnostycyzm antyczny i wspótczesna neognoza, red. idem, Warszawa 1996, s. 70; M. Nowak, Gnoza, ezoteryzm, romantyzm, w: Uniwersalizm chrześcijaństwa wobec alternatywnych propozycji współczesności, red.R.T. Ptaszek, M. Piwowarczyk, Lublin 2012, s. 259-281.

${ }^{17}$ V. Maldijeva, Strategie językowe podważania prawd chrześcijańskich we wspótczesnej kulturze Zachodu, w: Uniwersalizm chrześcijaństwa, s. 105-124.

${ }^{18}$ Zob. szkic: A. Zwoliński, Lalki bez twarzy, w: idem, Tajemne niemoce, Kraków 1994, s. 11; Ezoteryzm, okultyzm, satanizm w Polsce, red. S. Beźnic, Z. Pasek, Kraków 2005, s. 33-89.

${ }^{19}$ R. Rorty, Antyklerykalizm i ateizm, w: idem, G. Vattimo, Przyszłość religii, red. S. Zabala, Kraków 2010 (oryg. ang. 2005), s. 42. 
na differance $)^{20}$, której słowotwórcze nowatorstwo doceniłby pewnie Lem. „Różnia” - obok „dekonstrukcji” - jest najbardziej nośnym pojęciem w filozofii Jacques'a Derridy. Świat postmodernistyczny w wymiarze filozoficznym i heurystycznym jest zbiorem osobnych i osobistych narracji. Zmieniło to dociekania wielu dyscyplin humanistycznych w grę leksykalną, sprowadzając ustalenia historyków do „zabawy językiem”, bez odniesienia przedmiotowego. Dekonstrukcja spowodowała, że wszelkie opinie uznaje się za równoważne aksjologicznie. Odwrócono program platoński. Dialog nie ma doprowadzić do prawdy, a tylko sam dialog stał się prawdziwy. Rodzi to zagrożenie dla historii jako nauki i dla nauki w ogóle. Przejawy praktyczne to: odchodzenie od gruntownego badania na rzecz „snucia opowieści”, znacznie mniej czasochłonnego (co sprzyja szybkości karier), rozwój historiografii świadectw osobistych (tzw. intymistyki), w luźnym związku z kontekstem historycznym, oraz wkraczanie na grunt historii dyscyplin dotąd nie operujących ani jej warsztatem, metodologią, ani taką tradycją badawczą. Vattimo pisał, w myśl postmodernistycznej hermeneutyki, że skoro fakty są interpretacjami, to interpretacja jest jedynym faktem. Proponował przyswojenie sobie „chrześcijańskiej dziejowości", co umożliwi rozumienie korzeni kultury Zachodu. Zmiana taka już następuje. Jej przykładem jest umieszczanie w klasyfikacji nauk dziejów Kościoła w kategorii nauk pomocniczych religioznawstwa $^{21}$. Brak wiedzy o dogmatach dawnych kultów to rażąca luka warsztatowa u badaczy epok dawniejszych. Jak więc brak wiedzy o religiach egzystujących miałby być zaletą czy miernikiem kompetencji specjalistów dziejów nowoczesnych?

Postmodernizm dziwi się ponownej sakralizacji, która zachodzi w różnych aspektach życia, wyczuwając w tym ponadwyznaniowe napięcie transcendentne. A przecież już romantyczne ujęcia osoby kapłana-poety (np. polscy wieszczowie) i pisarza - nowoczesnego świętego (vide Victor Hugo), ale i uwielbienie przez odbiorców gwiazd show-businessu były zwiastunami tego zjawiska. Wspominał o tym Daniel Fabre, sugerując, że sakralizacja w obszarze kultury to skutek alfabetyzacji i wynika z roli przypisywanej w edukacji przekazowi kulturowemu. Można rozumieć ów proces jako sakralizację profanum (zwłaszcza popkulturowego) wskutek zaniku sacrum w życiu publicznym, zgadzając się z badaczem duchowości New Age Stevenem Sutcliffem ${ }^{22}$, że w istocie

${ }^{20}$ B. Baran, Postmodernizm, Kraków 1992, s. 123.

${ }^{21}$ Zob. Polska Klasyfikacja Tematyczna KBN, 〈kbn.icm.edu.pl/pub/kbn/docs/ pkt.html>, poz. 030000 i 033100.

${ }^{22}$ S. Sutcliffe, Children of the New Age. A History of Spiritual Practices, London-New York 2003. 
chodzi tu o pieniądze. Praktyki ubóstwienia ludzi wybitnych i widocznych w mediach wiążą się z ich interesem finansowym i związanych z nimi wytwórców, ale i aspiracjami fanów do duchowości, nazwanej „dysydencką”, tzn. przeciwną doktrynie oficjalnej, laicką (bo dotyczącą świeckich) i funkcjonalną (tj. organizującą codzienność poprzez zakup gadżetów, naśladowanie stroju, gustów i poglądów - w tym duchowości - idola). Poszukiwania religijne sięgają absurdu, jak „religia Jedi” (skutek popularności powstającej od lat siedemdziesiątych XX w. sagi filmowej Gwiezdne wojny), której wyznawców w Wielkiej Brytanii i Stanach Zjednoczonych Ameryki liczy się obecnie na setki tysięcy.

Poglądu, że upadek religii stanowi konieczny etap na drodze „ku postępowi", nie utrzymano jako pewnika interpretacyjnego. Przedstawione uwarunkowania i zjawiska, zachodzące w świecie globalizującym się, zmuszają do zastosowania nowego podejścia, co będzie rzutować na badania historyczne, nie tylko czasów najnowszych. Czy tzw. religijność delegowana ${ }^{22}$, gdy mniejszość praktykuje, a reszta jej w tym nie przeszkadza, znalazłszy się pod presją, w myśl wskazań Rorty'ego, nie zamieni się w religijność praktykowaną tajnie, krytykowaną przez areligijną lub zlaicyzowaną większość o rozproszonej świadomości wyznaniowej?

Gdyby to nastąpiło, historyk z przyszłości, jak Ijon Tichy na Dychtonii, być może nie będzie rozumiał przeszłości. Proces sekularyzacji utrudni bowiem badanie kultury własnej i tworzących ją więzi, jak zauważała Danièle Hervieu-Léger w pracy Religia jako pamięć. Sekularyzacja wyrastająca z dechrystianizacji i jako teoria interpretacyjna, i jako praktyka może zahamować lub zubożyć procedurę dekodowania informacji źródłowych w procesie poznania. Takie wyrugowanie interpretacji uważanych za „przestarzałe”, a zastąpienie ich nowymi sposobami „uprawiania" może znacząco przeobrazić to, co nazywamy poznaniem naukowym, co stałoby się sui generis paradoksem historii. Pod znakiem zapytania staną takie jej wyznaczniki, jak obiektywizm i zgodność interpretacji z faktami przemawiającymi ze źródeł. W ten sposób „szkiełko i oko” może zostać zastąpione kalejdoskopem.

${ }^{22}$ G. Davie, Religion in Britain since 1945. Believing without Belonging, Oxford-Cambridge, Mass. 1994, Making Contemporary Britain. 